\title{
PENGARUH PENAMBAHAN SARI BUAH SIRSAK (Annona muricata L.) TERHADAP KARAKTERISTIK YOGURT EDAMAME (Glycine max L.)
}

\author{
The Effect of Soursop (Annona muricata L.) Juice on the Characteristics of Edamame \\ (Glycine max L.) Yogurt
}

\author{
Dina Puti Kartika ${ }^{1)}$, I Dewa Gede Mayun Permana ${ }^{2)}$, Komang Ayu Nocianitri ${ }^{2)}$ \\ ${ }^{1)}$ Mahasiswa Program Studi Ilmu dan Teknologi Pangan, Fakultas Teknologi Pertanian, \\ Universitas Udayana \\ ${ }^{2)}$ Dosen Program Studi Ilmu dan Teknologi Pangan, Fakultas Teknologi Pertanian, Universitas \\ Udayana
}

\begin{abstract}
This study aims to determine the effect of soursop juice on the characteristics of edamame yogurt and to determine the optimal concentration of soursop juice to produce edamame yogurt with the best characteristics. This study used a Randomized Block Design (RBD) with the treatment of soursop fruit juice concentration consisting of 5 levels, namely $0 \%, 5 \%, 10 \%, 15 \%$ and $20 \%$. Each treatment was repeated 3 times, resulted in 15 experimental units. The data were analyzed by the Analysis of Variance (ANOVA) and if the treatment significantly affected the variables, the Duncan Multiple Range Test (DMRT) was performed. The results showed that the concentration of soursop juice significantly affected total $\mathrm{LAB}$, total acid, $\mathrm{pH}$, antioxidant activity, viscosity, sensory hedonic test on texture and sensory scoring test on texture and taste. The edamame yogurt with $15 \%$ soursop juice had the best characteristics with the following characteristics: total LAB $1.01 \times 10^{11} \mathrm{CFU} / \mathrm{ml}$, total acid $0.86 \%$, viscosity $310 \mathrm{cP}$, antioxidant activity $35.47 \%, \mathrm{pH} 3.72$ and the sensory properties of neutral scents, neutral appearance, a rather thick texture, a rather like taste, a slightly sour taste and a rather like overall reception.
\end{abstract}

Keywords: edamame yogurt, soursop juice, antioxidant activity

\section{PENDAHULUAN}

Konsumsi pangan hasil fermentasi semakin meningkat seiring dengan meningkatnya kesadaran masyarakat akan manfaatnya bagi kesehatan. Salah satu produk pangan hasil fermentasi yang mempunyai manfaat yang baik bagi kesehatan adalah yogurt. Yogurt adalah pangan hasil fermentasi susu yang mempunyai tekstur semi padat dengan citarasa yang khas (Widodo, 2003).

Yogurt yang umumnya populer di Indonesia adalah yogurt yang berasal dari susu sapi dan difermentasi menggunakan bakteri asam laktat yaitu Lactobacillus bulgaricus dan Streptococcus thermophillus. Yogurt tidak hanya dapat dibuat dari susu hewani, yogurt juga dapat dibuat dari campuran susu skim dengan

\footnotetext{
*Korespondensi Penulis:

E-mail: dinaputi@gmail.com ${ }^{1}$
}

susu nabati yaitu susu kacang-kacangan (Sumantri, 2004).

Salah satu bahan dari kacangkacangan yang sedang berkembang saat ini adalah kedelai sayur atau edamame. Edamame memiliki keunggulan yaitu memiliki kandungan protein (40\%). Edamame juga memiliki rasa yang lebih manis, tekstur yang lebih lembut dan mengandung sembilan asam amino esensial yang diperlukan tubuh (Rackis, 1978). Edamame juga mengandung sedikit lemak jenuh, kaya akan serat, vitamin $\mathrm{C}$ dan $\mathrm{B}$, serta kalsium, zat besi, magnesium, dan asam folat (Samruan et al., 2012).

Edamame juga dapat diolah menjadi susu edamame dan bila difermentasi oleh bakteri asam laktat akan menghasilkan yogurt edamame. Penelitian Rosiana (2016) mendapatkan perlakuan terbaik yogurt edamame pada konsentrasi 
kultur campuran bakteri asam laktat $7 \%$ dan waktu fermentasi selama 24 jam memiliki aktivitas antioksidan sebesar $19,18 \%$, dengan tingkat kesukaan yang rendah terhadap rasa dan aroma.

Penambahan sari buah sirsak dapat dilakukan untuk memperbaiki cita rasa dari yogurt edamame. Buah sirsak (Anonna muricata L.) memiliki rasa asam manis dan aroma yang harum (Nuswamarhaeni dan Saptarini, 1999). Selain itu, buah sirsak juga kaya akan serat pangan dan mengandung senyawa polifenol (Winarsi dan Hery, 2007), dan kaya akan vitamin C (Bora et al., 2004). Oleh karena itu penambahan sari buah sirsak diharapkan dapat meningkatkan aktivitas antioksidan dan cita rasa pada yogurt edamame. Rahmawati (2017) melaporkan bahwa penambahan sari buah murbei pada soyghurt (yogurt dari kedelai) berpengaruh terhadap viskositas, total asam, nilai $\mathrm{pH}$, dan cita rasa dari soyghurt.

Adapun faktor-faktor yang harus diperhatikan dalam penambahan sari buah sirsak pada yogurt adalah konsentrasi sari buah. Konsentrasi sari buah dapat mempengaruhi proses pembentukan curd pada yogurt dan akan mempengaruhi karakteristik yogurt yang akan dihasilkan. Oleh karena itu tujuan dari penelitian ini adalah untuk mengetahui bagaimana pengaruh penambahan sari buah sirsak terhadap karakteristik yogurt edamame dan untuk mengetahui konsentrasi penambahan sari buah sirsak yang optimal untuk menghasilkan yogurt edamame dengan karakteristik terbaik.

\section{METODE PENELITIAN Tempat dan Waktu Penelitian}

Penelitian ini dilaksanakan di UPT. Laboratorium Terpadu Biosains dan Bioteknologi Universitas Udayana, Laboratorium Analisis Pangan dan Laboratorium Biokimia \& Nutrisi Program Studi Ilmu dan Teknologi Pangan Fakultas Teknologi Pertanian Universitas Udayana. Pelaksanaan penelitian ini dilakukan pada bulan September sampai November 2018.

\section{Alat dan Bahan}

Bahan yang digunakan dalam penelitian ini meliputi edamame segar dan buah sirsak (diperoleh dari Supermarket Papaya Jln. Merta Nadi Kabupaten Badung), susu sapi "merk" Diamond, sukrosa (gula pasir) "merk" Gulaku (diperoleh dari Pepito Express Jln. Danau Batur Raya Kabupaten Badung), susu skim bubuk "merk" NZMP, gelatin "merk" Greenvalley (diperoleh dari Toko Subur Jaya Kimia Bandung), air mineral, isolat bakteri Lactobacillus rhamnosus SKG34 (Koleksi UPT. Laboratorium Biosains dan Bioteknologi), larutan saline, MRS (de Man Rogosa and Sharpe) Agar (Merck), MRS Broth, indikator fenolftalein $1 \%$, $\mathrm{NaOH}, \quad$ DPPH (2,2-diphenyllpicrylhydrazyl), aquadest, alkohol $70 \%$, etanol PA, alumunium foil, dan plastic wrap.

Alat yang dibutuhkan meliputi neraca analitik, blender, pisau, dan kain saring. Alat pasteurisasi yang digunakan dalam penelitian ini meliputi kompor, panci masak, sendok, termometer, jar kaca steril, tabung reaksi, cawan petri, autoklaf, pipet mikro, gelas ukur, Laminar Air Flow (JSCB-900SB), erlenmeyer (pyrex), refrigerator, inkubator (memmert), beaker glass (pyrex), bunsen, blue tip, yellow tip, Viscometer (Brookfield), $\mathrm{pH}$ meter, dan ose.

\section{Rancangan Penelitian}

Penelitian ini menggunakan Rancangan Acak Kelompok (RAK) dengan perlakuan konsentrasi buah sirsak yang terdiri dari 5 taraf yaitu $0 \%, 5 \%, 10 \%, 15 \%$, dan $20 \%$ dengan 3 kali ulangan sehingga diperoleh 15 unit percobaan. Data yang diperoleh dianalisis dengan Metode Analysis of Variance (ANOVA) menggunakan SPSS yang kemudian jika berpengaruh nyata dilanjutkan dengan Duncan Multiple Range Test (DMRT) pada taraf signifikasi 5\%.

\section{Pelaksanaan Penelitian}

Penelitian ini terdiri dari beberapa tahapan yaitu sebagai berikut:

1. Pembuatan kultur starter

Pembuatan kultur starter diawali dengan penyegaran kultur dimana $100 \mu l$ kultur stok dimasukkan ke dalam media $5 \mathrm{ml}$ MRS Broth dan diinkubasi selama 24 jam pada suhu $37^{\circ} \mathrm{C}$. 
Selanjutnya diambil $1 \mathrm{ml}$ dan dilanjutkan dengan pencucian sel yang dilakukan menggunakan centrifuge pada kecepatan $3200 \mathrm{rpm}$ selama 15 menit. Supernatan dibuang lalu ditambahkan larutan saline. Proses sentrifugasi diulang sebanyak 3 kali (Miller, 2000). Supernatan lalu dibuang dan isolat siap digunakan dalam pembuatan starter yogurt.

Massa sel yang diperoleh lalu diinokulasikan ke dalam susu sapi "merk" Diamond yang sudah dipasteurisasi selama 15 menit pada suhu $80^{\circ} \mathrm{C}$ dan sudah didiamkan pada suhu ruang hingga mencapai suhu optimum $\quad 42-45^{\circ} \mathrm{C}$. Selanjutnya ditambahkan $1 \%(\mathrm{v} / \mathrm{v})$ isolat yang sudah melewati proses pencucian sel. Selanjutnya diinkubasi pada suhu $43^{\circ} \mathrm{C}$ selama 17 jam dan dihasilkan starter. Starter yang dihasilkan dapat langsung digunakan untuk pembuatan yogurt edamame.

2. Pembuatan susu edamame

Susu edamame digunakan sebagai bahan baku utama dalam pembuatan yogurt. Pembuatan susu edamame ini mengacu pada penelitian Fitriyana (2014) yang dimodifikasi. Edamame yang sudah dicuci dengan air bersih direbus dengan air mendidih selama 10 menit sampai edamame matang. Biji-biji edamame lalu dipisahkan dengan kulitnya dan diitimbang sesuai dengan kebutuhan kemudian diblender sampai halus dengan perbandingan edamame dan air $1: 5$. Edamame yang sudah diblender kemudian disaring menggunakan kain saring agar terpisah antara susu edamame dengan ampas.

3. Pembuatan sari buah sirsak

Pembuatan sari buah sirsak mengacu pada penelitian Kartikasari (2014). Dipilih buah sirsak segar, tidak cacat dan memiliki kematangan yang baik. Buah sirsak selanjutnya dipotong dan dipisahkan dari kulit dan bijinya sehingga diperoleh daging buah. Daging buah sirsak dan air (1:1) selanjutnya dihancurkan dengan blender, kemudian dilakukan penyaringan agar terpisah antara sari buah dengan ampas.

4. Pembuatan yogurt edamame

Pembuatan yogurt edamame mengacu pada penelitian Fitriyana (2014) yang telah dimodifikasi, diawali dengan mencampurkan gelatin $0,15 \% \quad(\mathrm{~b} / \mathrm{v})$, sukrosa 5\% (b/v) dan susu skim 5\% (b/v) ke dalam susu edamame. Selanjutnya dipasteurisasi terlebih dahulu pada suhu $80^{\circ} \mathrm{C}$ selama 15 menit. Larutan tersebut lalu dimasukkan ke dalam jar kaca steril dan dicampurkan sari buah sirsak $(0 \%, 5 \%$, $10 \%, 15 \%, 20 \%$ ) yang sudah dipasteurisasi pada suhu $80^{\circ} \mathrm{C}$ selama 15 menit.

Campuran tersebut lalu didiamkan pada suhu ruang hingga mencapai suhu optimum kultur yaitu $42-45^{\circ} \mathrm{C}$. Kemudian ditambahkan dengan starter sebanyak 5\% (b/v). Inokulasi dilakukan dengan cara mendekatkan pada bunsen untuk mencegah kontaminasi. Tahap selanjutnya diinkubasi pada suhu $43^{\circ} \mathrm{C}$ selama 17 jam. Yogurt yang sudah membentuk koagulan yang baik kemudian dimasukkan ke dalam lemari pendingin untuk menghentikan proses fermentasi.

\section{Variabel yang Diamati}

Variabel yang diamati dalam penelitian ini adalah total BAL dengan metode Fardiaz (1993), total asam dengan metode AOAC (1995), uji pH menggunakan $\mathrm{pH}$ meter dengan metode AOAC (1998), aktivitas antioksidan metode DPPH menurut Widaghda dan Nisa (2015), viskositas dengan Viscometer Brookfield menurut Atkins (1994), uji keadaan sensoris menurut SNI 2981:2009 (BSN, 2009), serta uji sensoris menurut Soekarto (1985) yang meliputi uji hedonik dan skoring.

\section{HASIL DAN PEMBAHASAN \\ Total BAL}

Hasil analisis ragam menunjukan bahwa penambahan sari buah sirsak berpengaruh nyata $(\mathrm{P}<0,05)$ terhadap total BAL yogurt edamame. Nilai rata-rata total BAL yogurt edamame dapat dilihat pada Gambar 1. 


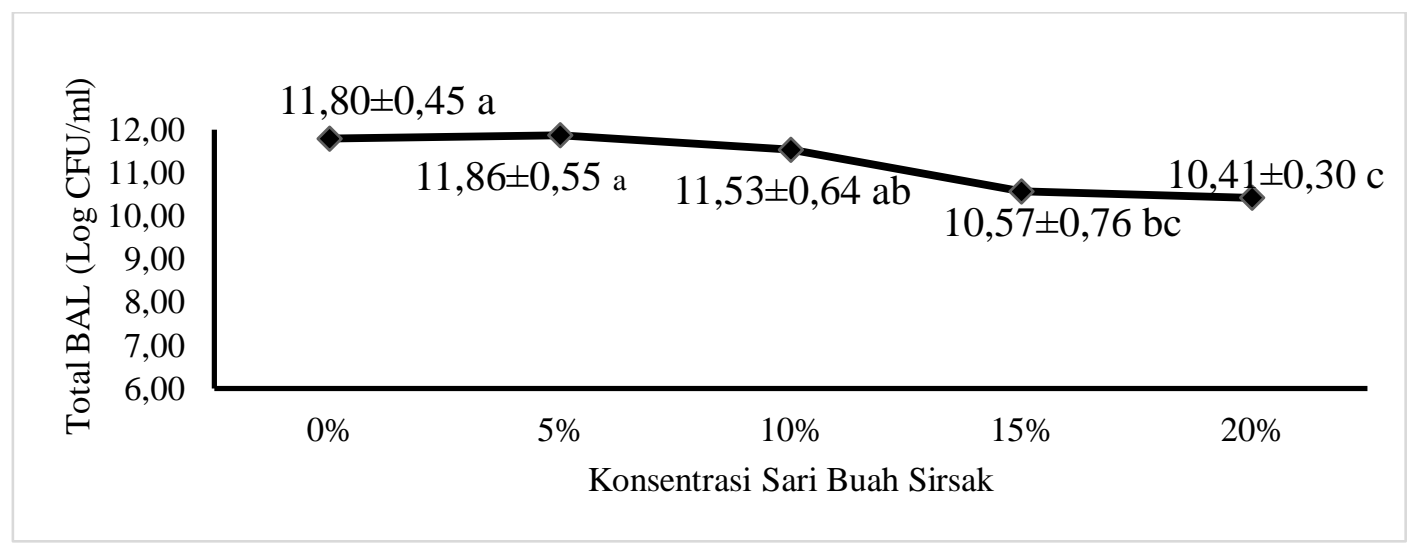

Gambar 1. Grafik pengaruh konsentrasi sari buah sirsak terhadap total BAL yogurt edamame

Penelitian ini menggunakan bakteri $L$. rhamnosus SKG34 sebagai kultur tunggal dalam proses fermentasi yogurt edamame. Proses fermentasi diawali dengan pemecahan gula yang terkandung dalam susu edamame dan sari buah sirsak. Total BAL pada yogurt edamame cenderung mengalami penurunan seiring meningkatnya konsentrasi sari buah sirsak.

Penurunan total BAL diduga karena adanya kandungan asam dan komponen antibakteri pada sari buah sirsak. Hal ini sesuai dengan pernyataan Buriti et al. (2017) yang melaporkan bahwa penambahan bahan yang berbahan dasar buah, baik dalam bentuk jus, sari buah ataupun pulp berpotensi memberikan efek negatif terhadap pertumbuhan dan viabilitas bakteri probiotik di dalam produk pangan yang disebabkan oleh kandungan asam dan komponen antimikroba yang terkandung di dalam buah. Menurut penelitian Otto et al. (2015), buah sirsak segar dan buah sirsak yang difermentasi menghasilkan metabolit yang terbukti mempunyai aktivitas antibakteri terhadap bakteri gram negatif dan bakteri gram positif.

Buah sirsak mengandung senyawa antioksidan seperti polifenol, flavonoid, dan tanin. Kandungan bahan aktif yang terdapat pada buah sirsak diduga mempunyai daya antibakteri terhadap $L$. rhamnosus SKG34. Hal ini sesuai dengan Pourmouran (2006) yang menyatakan bahwa kandungan polifenol berfungsi sebagai antibakteri. Menurut Ajizah
(2004), tanin juga mampu mengkerutkan dinding sel bakteri sehingga permeabilitas sel bakteri terganggu dan pertumbuhannya terhambat.

Walaupun total BAL pada yogurt edamame mengalami penurunan, total BAL yang dihasilkan masih berkisar antara $1,15 \times 10^{12} \mathrm{CFU} / \mathrm{ml}$ sampai $5,72 \times 10^{10}$ CFU/ml dimana kisaran tersebut masih dalam ketentuan SNI yogurt 2981:2009 yaitu syarat jumlah bakteri minimal $1 \times 10^{7}$ $\mathrm{CFU} / \mathrm{ml}$. Penelitian ini menunjukkan bahwa penambahan sari buah sirsak sebanyak $5 \%$ dan $10 \%$ menghasilkan pertumbuhan bakteri asam laktat yang baik.

\section{Total Asam Laktat}

Hasil analisis ragam menunjukan bahwa yogurt edamame tanpa penambahan sari buah sirsak berpengaruh sangat nyata $(\mathrm{P}<0,01)$ terhadap total asam laktat yogurt edamame dengan penambahan sari buah sirsak. Total asam laktat tertinggi terdapat pada yogurt edamame tanpa penambahan sari buah sirsak yaitu $1,02 \%$ dan sementara total asam laktat terendah terdapat pada konsentrasi sari buah sirsak $20 \%$ yaitu $0,86 \%$. Nilai rata-rata total asam laktat yogurt edamame dapat dilihat pada Gambar 2.

Total asam laktat mengalami penurunan yang signifikan semakin tinggi konsentrasi sari buah sirsak yang ditambahkan. L. rhamnosus SKG34 merupakan BAL homofermentatif yakni BAL yang menghasilkan asam laktat 
sebagai produk utama dari fermentasi gula (Sujaya et al., 2008). Selama proses fermentasi, bakteri asam laktat (BAL) akan menghasilkan asam laktat dengan memecah gula yang terdapat pada susu edamame dan sari buah sirsak. Perubahan kadar asam laktat juga sebanding dengan total BAL yang didapat dalam yogurt dimana total BAL juga semakin menurun seiring bertambahnya konsentrasi sari buah sirsak. Hal ini dikarenakan peningkatan jumlah sel BAL akan menyesuaikan produksi asam laktat (Kowskoski, 1977 dan Taufik, 2004). Walaupun mengalami penurunan, nilai rata-rata total asam laktat yang dihasilkan oleh kelima perlakuan masih dalam range ketentuan dalam SNI yaitu $0,5-2,0 \%$.

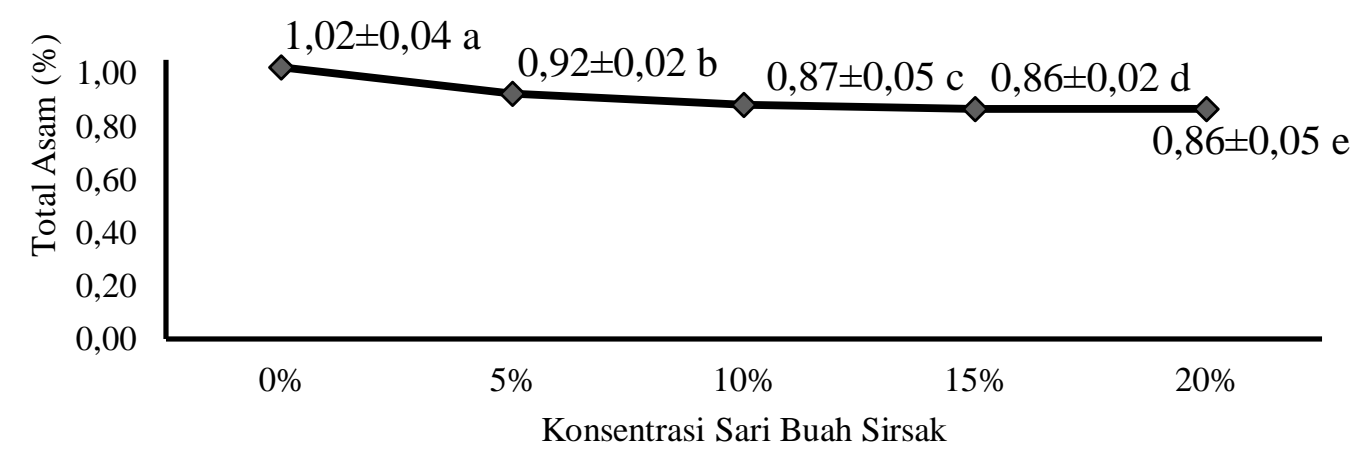

Gambar 2. Grafik pengaruh konsentrasi sari buah sirsak terhadap total asam laktat yogurt edamame

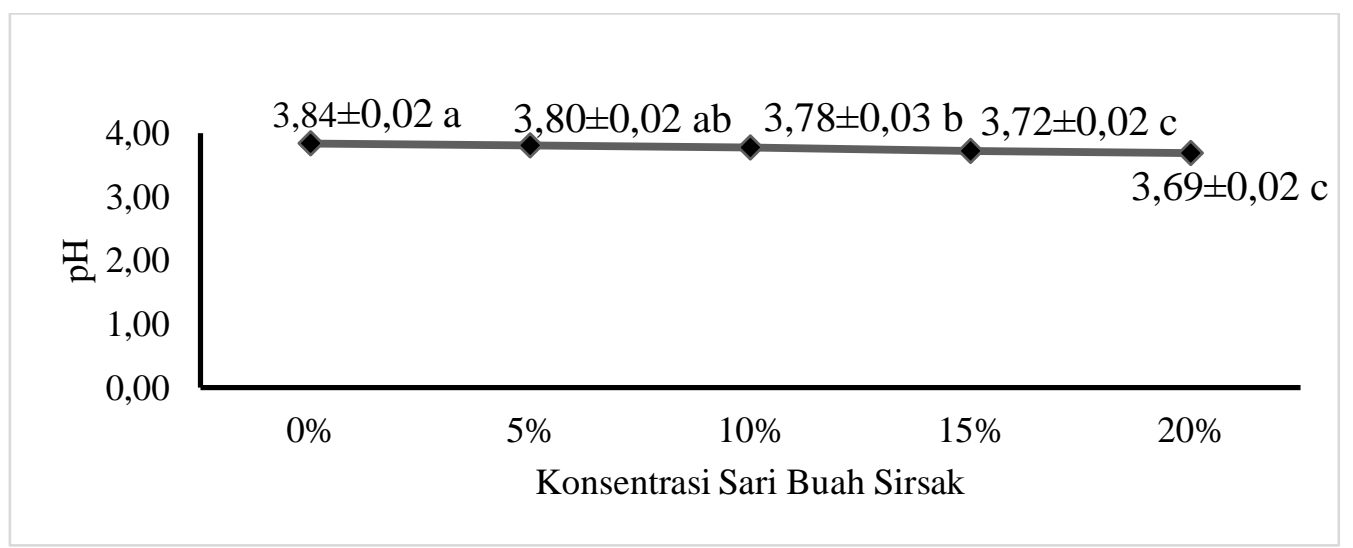

Gambar 3. Grafik pengaruh konsentrasi sari buah sirsak terhadap $\mathrm{pH}$ yogurt edamame

pH

Hasil analisis ragam menunjukan bahwa penambahan sari buah sirsak berpengaruh sangat nyata $(\mathrm{P}<0,01)$ terhadap $\mathrm{pH}$ yogurt edamame. Nilai ratarata $\mathrm{pH}$ yogurt edamame dapat dilihat pada Gambar 3. Derajat keasaman $(\mathrm{pH})$ yogurt edamame dapat dilihat mengalami penurunan seiring dengan meningkatnya konsentrasi sari buah sirsak. $\mathrm{pH}$ yogurt edamame tanpa penambahan buah sirsak memiliki pH tertinggi yaitu 3,84.

Penurunan $\mathrm{pH}$ pada yogurt edamame tidak hanya dipengaruhi oleh asam laktat yang dihasilkan oleh bakteri asam laktat selama proses fermentasi karena total asam laktat mengalami penurunan seiring bertambahnya 
konsentrasi sari buah sirsak. Sehingga diduga kandungan asam pada sari buah sirsak mempunyai kontribusi yang lebih besar dalam penurunan $\mathrm{pH}$ yogurt. Menurut penelitian Badrie dan Schauss (2010), Morton (1987), dan Enweani et al. (2004), kandungan asam yang banyak terdapat dalam buah sirsak antara lain adalah asam askorbat, asam sitrat, dan asam malat.

Asam yang terdapat pada sari buah sirsak tergolong kedalam asam lemah, sama halnya dengan asam laktat. Namun kekuatan asam dari asam sitrat dan asam malat lebih tinggi dibandingkan dengan kekuatan asam laktat dimana nilai persentase tetapan ionisasi asam sitrat adalah $8,6 \%$ dan asam malat $4 \%$. Sementara persentase nilai tetapan asam laktat sendiri adalah $1,4 \%$ sehingga memiliki kekuatan asam yang lebih rendah. Hal ini sesuai dengan teori menurut Bettelheim dan Landesberg (2007) yang menyatakan bahwa semakin besar tetapan ionisasi suatu senyawa asam maka semakin kuat asam tersebut karena sebagian besar asam tersebut terdisosiasi menjadi ionionnya.

\section{Aktivitas Antioksidan}

Hasil analisis ragam menunjukan bahwa penambahan sari buah sirsak berpengaruh nyata $(\mathrm{P}<0,05)$ terhadap aktivitas antioksidan yogurt edamame. Nilai rata-rata aktivitas antioksidan dapat dilihat pada Gambar 4. Aktivitas antioksidan pada yogurt edamame mengalami peningkatan yang signifikan seiring dengan penambahan sari buah sirsak. Penambahan sari buah sirsak dengan konsentrasi $20 \%$ memiliki nilai rata-rata aktivitas antioksidan tertinggi yaitu $40,47 \%$. Sementara penambahan sari buah sirsak dengan konsentrasi $0 \%$ memiliki nilai rata-rata aktivitas antioksidan terendah yaitu $24,58 \%$ namun nilai ini tidak berbeda nyata dengan penambahan sari buah sirsak dengan konsentrasi 5\% yaitu $26,7 \%$.

Hasil penelitian menunjukan bahwa semakin tinggi konsentrasi sari buah sirsak yang ditambahkan ke dalam yogurt edamame akan meningkatkan kemampuan menangkal senyawa radikal bebas. Agu dan Okolie (2017) melaporkan bahwa tanaman sirsak mengandung senyawa alkaloid, flavonoid dan fenol yang tinggi terutama pada bagian buah dan daun. Senyawa fitokimia yang terdapat pada buah sirsak antara lain adalah tanin, flavonoid, saponin, terpenoid, alkaloid, steroid, dan fenol. Senyawa-senyawa tersebut dapat meningkatkan potensi antioksidan pada yogurt edamame dan menjelaskan mengapa aktivitas antioksidan semakin meningkat seiring meningkatnya konsentrasi sari buah sirsak

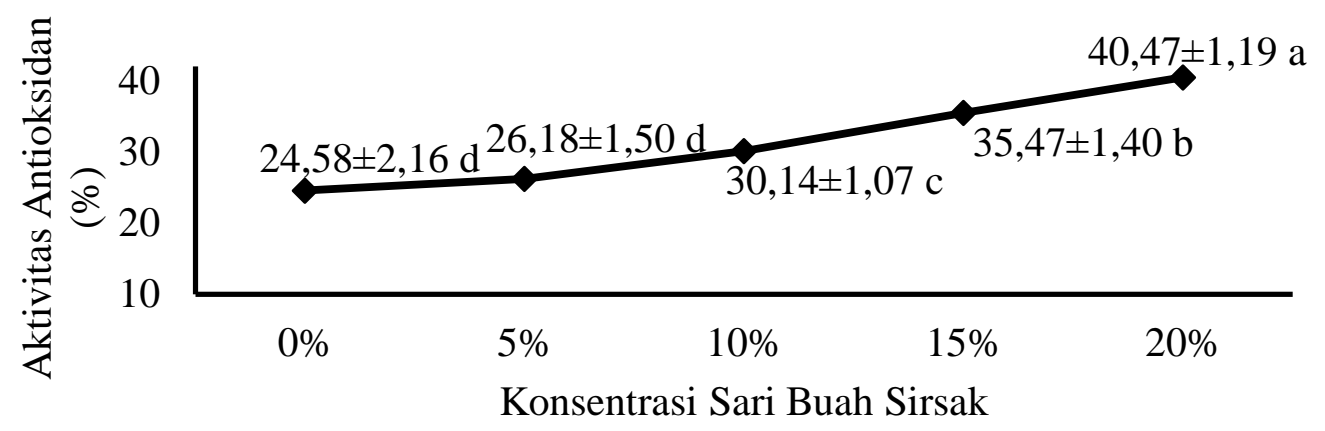

Gambar 4. Grafik pengaruh konsentrasi sari buah sirsak terhadap aktivitas antioksidan yogurt edamame

\section{Viskositas}

Hasil analisis ragam menunjukan bahwa penambahan sari buah sirsak berpengaruh nyata $(\mathrm{P}<0,05)$ terhadap viskositas yogurt edamame. Pengukuran viskositas digunakan untuk mengetahui 
perubahan kekentalan yogurt yang dihasilkan. Nilai rata-rata viskositas yogurt edamame dapat dilihat pada Gambar 5. Pada proses pembuatan yogurt edamame, terkandung kandungan karbohdirat yang dapat difermentasi oleh bakteri L. rhamnosus SKG 34. Dalam proses fermentasi tersebut bakteri asam laktat akan menghasilkan asam laktat yang menyebabkan terjadinya penurunan $\mathrm{pH}$ susu sehingga protein yang terkandung mengalami denaturasi dan membentuk curd. Maka dihasilkan yogurt dengan tekstur yang kental, dimana viskositas tertinggi didapatkan oleh yogurt edamame dengan konsentrasi sari buah sirsak 5\% yaitu $460 \mathrm{cP}$.

Namun viskositas yogurt edamame cenderung mengalami penurunan seiring dengan meningkatnya konsentrasi sari buah sirsak. Yogurt edamame dengan konsentrasi sari buah sirsak $20 \%$ memiliki nilai rata-rata viskositas paling rendah. Penambahan sari buah sirsak akan meningkatkan kandungan air sementara bahan lainnya seperti susu edamame, susu skim, gula, dan gelatin masih dalam jumlah yang tetap. Maka itu semakin tinggi konsentrasi sari buah sirsak maka semakin menurun nilai viskositas yogurt.

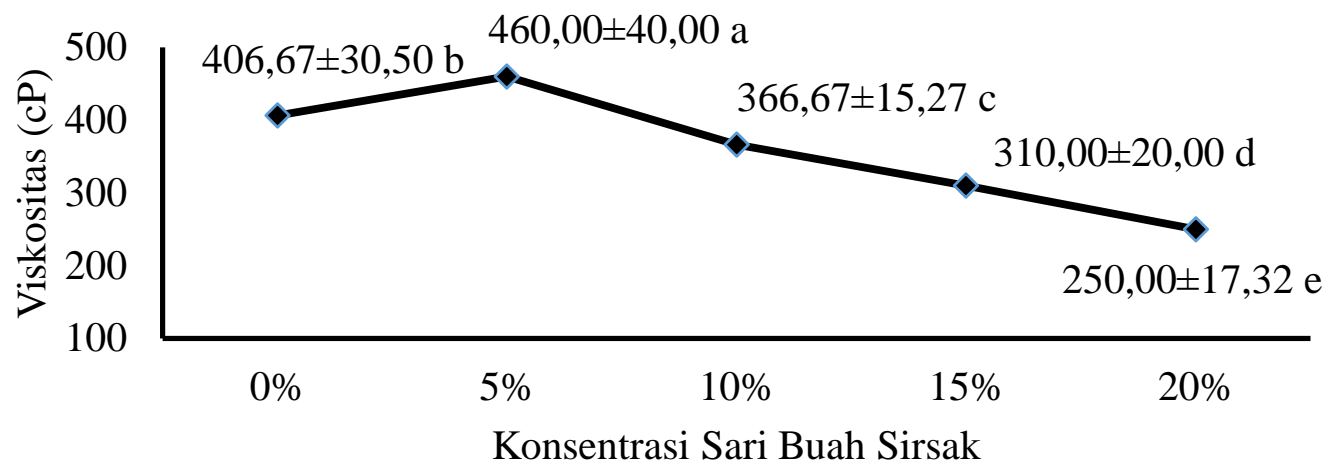

Gambar 5. Grafik pengaruh konsentrasi sari buah sirsak terhadap viskositas yogurt edamame

\section{Hasil Uji Sensoris Tekstur}

Hasil analisis ragam menunjukan bahwa perbedaan konsentrasi sari buah sirsak berpengaruh sangat nyata $(\mathrm{P}<0,01)$ terhadap tekstur yogurt edamame. Nilai rata-rata uji skoring terhadap tekstur yogurt edamame adalah 1,8-4 dengan kriteria tidak kental sampai agak kental (Tabel 1). Sementara nilai rata-rata uji hedonik terhadap tekstur yogurt edamame adalah 3,7-4,8 dengan kriteria agak tidak suka sampai biasa. Yogurt edamame dengan penambahan konsentrasi sari buah sirsak $20 \%$ mempunyai nilai rata-rata terendah yaitu 1,8 (tidak kental) pada uji skoring dan 3,7 (agak tidak suka) pada uji hedonik. Sementara yogurt edamame dengan penambahan konsentrasi sari buah sirsak 5\% mempunyai nilai rata-rata tertinggi yaitu 4,07 (agak kental) pada uji hedonik dan 4,8 (biasa) pada uji hedonik.

Hasil uji sensoris tekstur menunjukan hasil yang hampir sama dengan hasil uji viskositas dimana tekstur yogurt edamame cenderung mengalami penurunan. Hal ini disebabkan karena penambahan sari buah sirsak akan meningkatkan kandungan air dalam susu edamame sehingga viskositas yogurt semakin rendah. Walaupun demikian, hasil uji keadaan menurut SNI (Tabel 3) menunjukan kelima perlakuan yogurt edamame memiliki konsistensi "normal" dimana komponen padat tidak terpisah dengan cairannya (homogen). 
Tabel 1. Nilai rata-rata hasil uji sensoris skoring dan hedonik yogurt edamame terhadap tekstur dan rasa

\begin{tabular}{ccccc}
\hline \multirow{2}{*}{$\begin{array}{c}\text { Konsentrasi sari } \\
\text { buah sirsak }\end{array}$} & \multicolumn{2}{c}{ Tekstur } & \multicolumn{2}{c}{ Rasa } \\
\cline { 2 - 5 } & Skoring & Hedonik & Skoring & Hedonik \\
\hline $0 \%$ & $3,73 \pm 0,45 \mathrm{a}$ & $4,80 \pm 1,47 \mathrm{a}$ & $3,80 \pm 1,01 \mathrm{~b}$ & $4,80 \pm 1,14 \mathrm{a}$ \\
$5 \%$ & $4,07 \pm 0,88 \mathrm{a}$ & $4,60 \pm 1,30 \mathrm{a}$ & $4,00 \pm 0,75 \mathrm{~b}$ & $4,73 \pm 1,33 \mathrm{a}$ \\
$10 \%$ & $3,13 \pm 0,91 \mathrm{~b}$ & $4,60 \pm 1,30 \mathrm{a}$ & $4,13 \pm 0,64 \mathrm{~b}$ & $4,73 \pm 1,10 \mathrm{a}$ \\
$15 \%$ & $3,07 \pm 0,70 \mathrm{~b}$ & $4,20 \pm 1,47 \mathrm{ab}$ & $4,60 \pm 0,50 \mathrm{a}$ & $5,07 \pm 1,10 \mathrm{a}$ \\
$20 \%$ & $1,80 \pm 1,01 \mathrm{c}$ & $3,73 \pm 1,33 \mathrm{~b}$ & $4,73 \pm 1,45 \mathrm{a}$ & $4,60 \pm 1,63 \mathrm{a}$ \\
\hline
\end{tabular}

Keterangan:

- Nilai rata-rata yang memiliki huruf yang sama dibelakang pada kolom menunjukan perlakuan berbeda tidak nyata $(\mathrm{P}>0,05)$

- Kriteria penilaian untuk uji hedonik tekstur dan rasa: 1 (sangat tidak suka), 2 (tidak suka), 3 (agak tidak suka), 4 (biasa), 5 (agak suka), 6 (suka), 7 (sangat suka)

- Kriteria penilaian untuk uji skoring terhadap tekstur: 1 (tidak kental), 2(agak tidak kental), 3 (biasa), 4(agak kental), 5 (kental)

- Kriteria penilaian untuk uji skoring terhadap rasa: 1 (tidak asam), 2 (agak tidak asam), 3 (biasa), 4 (agak asam), 5 (asam)

Tabel 2. Nilai rata-rata hasil uji sensoris hedonik yogurt edamame terhadap penampakan, aroma dan penerimaan keseluruhan.

\begin{tabular}{cccc}
\hline $\begin{array}{c}\text { Konsentrasi } \\
\text { Sari Buah Sirsak }\end{array}$ & Penampakan & Aroma & $\begin{array}{c}\text { Penerimaan } \\
\text { Keseluruhan }\end{array}$ \\
\hline $0 \%$ & $5,13 \pm 0,10 \mathrm{a}$ & $4,40 \pm 0,91 \mathrm{a}$ & $4,87 \pm 0,83 \mathrm{a}$ \\
$5 \%$ & $5,27 \pm 1,16 \mathrm{a}$ & $4,60 \pm 1,12 \mathrm{a}$ & $5,00 \pm 1,00 \mathrm{a}$ \\
$10 \%$ & $5,13 \pm 0,74 \mathrm{a}$ & $4,33 \pm 1,11 \mathrm{a}$ & $5,00 \pm 0,84 \mathrm{a}$ \\
$15 \%$ & $4,80 \pm 1,26 \mathrm{a}$ & $4,87 \pm 1,18 \mathrm{a}$ & $5,13 \pm 1,24 \mathrm{a}$ \\
$20 \%$ & $4,67 \pm 1,39 \mathrm{a}$ & $4,67 \pm 1,34 \mathrm{a}$ & $4,87 \pm 1,40 \mathrm{a}$ \\
\hline
\end{tabular}

Keterangan:

- Nilai rata-rata yang memiliki huruf yang sama dibelakang pada kolom menunjukan perlakuan berbeda tidak nyata $(\mathrm{P}>0,05)$

- Kriteria penilaian untuk uji hedonik penampakan, aroma, dan penerimaan keseluruhan: 1 (sangat tidak suka), 2 (tidak suka), 3 (agak tidak suka), 4 (biasa), 5 (agak suka), 6 (suka), 7 (sangat suka)

Tabel 3. Hasil uji keadaan (sifat sensoris) yogurt menurut SNI 2981:2009

\begin{tabular}{cclll}
\hline $\begin{array}{c}\text { Konsentrasi Sari } \\
\text { Buah Sirsak }\end{array}$ & Penampakan & Bau & Rasa & Konsistensi \\
\hline $0 \%$ & Normal & Normal & Normal & Homogen \\
$5 \%$ & Normal & Normal & Normal & Homogen \\
$10 \%$ & Normal & Normal & Normal & Homogen \\
$15 \%$ & Normal & Normal & Normal & Homogen \\
$20 \%$ & Normal & Normal & Normal & Homogen \\
\hline \multirow{2}{*}{ Rasa } & & rasa yogurt edamame adalah 3,8-4,7 \\
& Hasil analisis ragam menunjukan & dengan kriteria biasa sampai agak asam & (Tabel 1). Yogurt edamame tanpa \\
bahwa & konsentrasi & sari buah sirsak & penambahan sari buah sirsak mempunyai \\
berpengaruh sangat nyata (P<0,01) & nilai rata-rata terendah pada uji skoring \\
terhadap rasa yogurt edamame pada uji & yaitu 3,8 dengan kriteria biasa. Hasil uji \\
skoring. Nilai rata-rata uji skoring terhadap & keadaan menurut SNI (Tabel 5) juga
\end{tabular}


menunjukan rasa yogurt edamame dari kelima perlakuan termasuk ke dalam kategori normal, dimana rasa yogurt edamame memiliki rasa asam khas yogurt dan tidak memiliki rasa asing selain rasa yogurt.

Yogurt edamame memiliki rasa yang semakin asam seiring dengan meningkatnya konsentrasi sari buah sirsak dimana yogurt edamame dengan konsentrasi sari buah sirsak $20 \%$ memiliki nilai rata-rata skoring rasa tertinggi yaitu 4,7 (agak asam). Rasa yang terbentuk pada yogurt edamame berhubungan dengan proses fermentasi oleh bakteri L. rhamnosus SKG34 dan menghasilkan asam laktat yang memberikan rasa asam pada yogurt. Selain asam laktat, kandungan asam dari sari buah sirsak juga mempengaruhi rasa dari yogurt edamame seperti asam sitrat, asam malat dan asam askorbat (Badrie dan Schauss, 2010). Namun hasil analisis ragam untuk uji hedonik menunjukan bahwa konsentrasi sari buah berpengaruh tidak nyata $(\mathrm{P}>0,05)$ terhadap rasa yogurt edamame. Hal ini diduga disebabkan karena rasa asam yang mendominasi rasa yogurt edamame dimana kisaran $\mathrm{pH}$ yogurt edamame (Tabel 3) adalah 3,84 hingga 3,69. Nilai $\mathrm{pH}$ ini lebih rendah dibandingkan dengan $\mathrm{pH}$ yogurt pada umumnya yaitu 4,00 .

\section{Penampakan}

Hasil analisis ragam menunjukan bahwa konsentrasi sari buah sirsak berpengaruh tidak nyata $(\mathrm{P}>0,05)$ terhadap penampakan yogurt edamame. Nilai ratarata uji hedonik terhadap penampakan yogurt edamame berkisar antara 4,8-5,27 dengan kriteria biasa sampai agak suka (Tabel 2). Hasil uji keadaan menurut SNI juga menunjukan bahwa kelima perlakuan yogurt edamame tersebut memiliki penampakan yang normal, yaitu masih tergolong kedalam cairan yang kental.

\section{Aroma}

Hasil analisis ragam menunjukan bahwa konsentrasi sari buah sirsak berpengaruh tidak nyata $(\mathrm{P}>0,05)$ terhadap aroma yogurt edamame. Nilai rata-rata uji hedonik terhadap aroma yogurt edamame berkisar antara 4,87-4,33 dengan kriteria biasa (Tabel 2). Sementara hasil uji keadaan SNI menunjukkan bahwa aroma yogurt edamame termasuk ke dalam kategori normal dimana yogurt edamame dari kelima perlakuan tersebut memiliki aroma asam khas yogurt dan tidak tercium bau asing lainnya.

Aroma dihasilkan karena adanya komponen volatil yang berasal dari produk yang dapat terdeteksi oleh indera pembau. Aroma edamame masih bisa terdeteksi dimana komponen volatil pemberi aroma tersebut adalah (Z)-3-hexenyl acetate, linalool, acetophenone, dan cis-jasmone. Beberapa komponen pemberi aroma yang terdapat dalam edamame antara lain adalah hexanal, 1- hexanol, (E)-2-hexenal, 1octen-3-ol, dan 2-pentylfuran (Sugawara et al. 1988). Sari buah sirsak juga memiliki komponen volatil yang mempengaruhi aroma yogurt edamame adalah senyawa ester seperti methyl butyrate, ethyl acetate, dan butyl acetate (Badrie dan Schauss, 2010).

\section{Penerimaan Keseluruhan}

Hasil analisis ragam menunjukan bahwa konsentrasi sari buah sirsak berpengaruh tidak nyata $(\mathrm{P}>0,05)$ terhadap penerimaan keseluruhan yogurt edamame. Nilai rata-rata uji hedonik terhadap penerimaan keseluruhan yogurt edamame berkisar antara 4,87-5,13 dengan kriteria biasa sampai agak suka (Tabel 2).

\section{KESIMPULAN DAN SARAN}

\section{Kesimpulan}

Berdasarkan penelitian yang dilakukan, dapat disimpulkan beberapa hal sebagai berikut:

1. Konsentrasi sari buah sirsak berpengaruh terhadap total BAL, total asam, $\mathrm{pH}$, aktivitas antioksidan, viskositas, tekstur (uji hedonik dan uji skoring) dan rasa (uji skoring) yogurt edamame. Sedangkan konsentrasi sari buah sirsak berpengaruh tidak nyata terhadap rasa, penampakan, aroma, dan penerimaan keseluruhan (uji hedonik) yogurt edamame.

2. Konsentrasi sari buah sirsak $15 \%$ menghasilkan karakteristik yogurt 
edamame yang terbaik dimana karakteristik total BAL 1,01 x $10^{11}$ $\mathrm{CFU} / \mathrm{ml}$, total asam $0,86 \%$, viskositas $310 \mathrm{cP}$, aktivitas antioksidan $35,47 \%$, $\mathrm{pH} 3,72$ serta sifat sensori aroma biasa, penampakan biasa, tekstur netral, tekstur biasa, rasa agak suka, rasa agak asam, dan penerimaan keseluruhan agak suka.

\section{Saran}

1. Perlu dilakukan penelitian mengenai perbandingan jumlah edamame dengan air dalam pembuatan susu edamame dan pengaruhnya terhadap karakteristik yogurt edamame

2. Perlu dilakukan penelitian mengenai pengaruh penggunaan ekstrak sari buah sirsak yang lebih pekat terhadap karakteristik yogurt edamame

\section{DAFTAR PUSTAKA}

Agu, K.C. dan P. N. Okolie. 2017. Proximate Composition, Phytochemical Analysis, and In Vitro Antioxidant Potentials of Extracts of Annona muricata (Soursop). Food Sci Nutr. 2017;5:1029-1036.

Agustina, W dan Y. Andriana. 2010. Karakteristik Produk Yoghurt Susu Nabati Kacang Hijau (Phaseolus radiatus $\mathrm{L}$ ). Balai Besar Pengembangan Teknologi Tepat Guna-LIPI. Jawa Barat.

Ajizah, A. 2004. Sensitivitas Salmonella typhimurium Terhadap Ekstrak Daun Psidium Guajava L. Bioscientiae 1(1):31-38.

Anonimus. 2012. Nutrient, Phytochemical Composition and Sensory Evaluation of Soursop (Annona muricata) Pulp and Drink in South Eastern Nigeria. Departement of Home Science, Nutrition and Dietetics. International Journal of Basic \& Applied Science IJBAS-IJENS. University of Nigeria.

AOAC. 1995. Official Methods of Analysis of AOAC International. Washington DC: AOAC Intl.
AOAC. 1998. Official Methods of Analysis of AOAC International. AOAC USA: International Virginia.

Atkins, P.W. 1994. Kimia Fisika Jilid 1. Jakarta: Erlangga.

Badan Standardisasi Nasional (BSN). 2009. Syarat Mutu Yogurt menurut SNI 2981:2009.

Badrie, N. dan A.G. Schauss. 2010. Soursop (Annona muricata L.): Composition, Nutritional Value, Medicinal Uses, and Toxicology. Bioactive Foods in Promoting Health: Fruits and Vegetables, Elsevier Inc. pp. 622-643.

Bettelheim, F. A. \& J. M Landesberg. 2007. Laboratory Experiments for General, Organic, and Biochemistry, 6th edition. Chaput, J.C. ISBN-13: 9780495015048.

Bora, P., H. Holsuch. \& V. MAS. 2004. Characterization of polyphenol oxidase of soursop (Annona muricata L.) fruit and comparative study. Cienciay Tecnologia Alimentaria, pp. 267-273.

Buriti, F.C.A., T.R. Komatsu, dan S. M. I. Saad. 2007. Acticity of passion fruit (Passiflora edulis) and guava (Psidium guajava) pulps on Lactobacillus acidophilus in refrigated mousses. Brazilian Journal of Microbiology 38. pp. 315-317.

Enweani, I.B., J. Obroku, T. Enahoro, dan C. Omoifo. 2004. The biochemical analysis of soursop (Annona muricata L.) and sweetsop (A. squamosa L.) and their potential use as oral rehydration therapy. Food, Agriculture \& Environment, Helsink, n.2. pp. 39-43.

Fardiaz, S. 1993. Analisis Mikrobiologi Pangan. Bogor: PAU IPB.

Fitriyana, N. I. 2014. Pengembangan Pangan Fungsional Antikolesterol Dari Kedelai Edamame (Glycine Max (L) Merril). Skripsi. Universitas Jember. 
Fraizer, W.C dan D. Westhoff. 1978. Food Agrobiology. 3rd edition. McGrawHill Book Company, New York.

Kartikasari, D. I. dan F.C. Nisa. 2014. Pengaruh Penambahan Sari Buah Sirsak Dan Lama Fermentasi Terhadap Karakteristik Fisik Dan Kimia Yogurt. Jurnal Pangan dan Agroindustri, 2(4), pp. 239-248.

Kosikowski, F.V. 1977. Cheese and Fermented Milk Foods. 2nd Edition. Edwards Brothers. Inc. Ann Arbor. pp 437-440.

Miller J.N. 2000. Statistics and Chemometrics for Analytical Chemistry, 4th ed. Harlow: Prentice. Hall.

Morton, J. 1987. Fruits of Warm Climates. Media. Winterville, NC: Creative Resource Systems, Inc. pp. 75-80.

Nuswamarhaeni dan Saptarini, 1999. Mengenal buah unggul Indonesia. Penebar Swadaya. Jakarta. 341 hlm.

Otto, R.B.D., N. Maureen, dan S. Duncan. 2015. Comparison of Antibacterial Activities of Fermented with those of Unfermented Annona muricata (L) Fruit Extracts. International Journal of Current Microbiology and Applied Sciences. pp. 696-707.

Pourmouran, F., S.J. Hosseinimehr, dan N. Shahabimajd. 2006. Antioxidant Activity, Phenol and Flavonoid Contents of Some Selected Iranian Medicinal Plants.African journal of Biotechnology Vol. 5(11) : 11421145, 2006

Rackis, J.J. 1978. Biochemical Changes in Soybeans: Maturation, Post-Harvest Storage and Processing, and Germination. In: Hultin, H.O. and Milner M. (eds.) Post Harvest Biology and Technology. Food \& Nutrition, Westport.

Rahmawati, D., dan K. Joni. 2017. Penambahan Sari Buah Murbei (Morus alba L.) dan Gelatin terhadap
Karakteristik Fisiko-Kimia dan Mikrobiologi Yoghurt Susu Kedelai. Jurnal Pangan dan Agroindustri Vol 5 No 3:83-94. Universitas Brawijaya, Malang.

Rosiana, N. M., 2016. Karakteristik Yogurt Edamame Hasil Fermentasi Kultur Campuran Bakteri Asam Laktat Komersial Sebagai Pangan Fungsional Berbasis Biji-Bijian. Seminar Hasil Penelitian dan Pengabdian Masyarakat Dana BOPTN, pp. 33-37.

Samruan, W., R. Oonsivilai, dan A. Oonsivilai, 2012. Soybean and Fermented Soybean Extract Antioxidant Activity. World Academy of Science, Engineering and Technology.

Soekarto. 1985. Penilaian Organoleptik untuk Industri Pangan dan Hasil Pertanian. Jakarta: Bharata Karya Aksara.

Sumantri, I., 2004. Pemanfaatan Mangga Lewat Masak Menjadi Fruitghurt dengan Mikroorganisme Lactobacillus bulgaricus. Prosiding Seminar Nasional Rekayasa Kimia dan Proses. Jurusan Teknik Kimia Fakultas Teknik UNDIP.

Sugawara, E., T. Ito, S. Odagiri, K. Kubota, and A. Kobayashi. 1988. Changes in Aroma Components of Green Soybeans with Maturity. Nihon Nogei Kagaku Kaishi 62:148-55

Sujaya, I. N., Y. Ramona, N.M. Utami D., N. L.P. Suariani, N.P. Widarini, K.A. Nocianitri dan N.W. Nursini. 2008. Isolation and Characterization of Lactic Acid Bacteria from Sumbawa Mare Milk. J.Vet. 9:52-59.

Taufik, E. 2004. Dadih Susu Sapi Hasil Fermentasi Berbagai Starter Bakteri Probiotik yang Disimpan Pada Suhu Rendah: Karakteristik Kimiawi. Jurnal Media Peternakan Vol 27 No.3. pp 88100.

Widagdha, S. dan F. C. Nisa. 2015. Pengaruh Penambahan Sari Anggur 
(Vitis vinifera L.) dan Lama Fermentasi Terhadap Karakteristik Fisiko Kimia Yoghurt. Jurnal Pangan dan Agroindustri Vol. 3 No 1 p,248258.

Widodo. 2003. Bioteknologi Industri Susu. Lacticia Press. Andi Offset. Yogyakarta.
Winarsi dan Hery. 2007. Antioksidan Alami dan Radikal Bebas: Potensi dan Aplikasinya Dalam Kesehatan. Kanisius, Yogyakarta. 